\title{
Switching Overvoltages Protection of Power Electronics Converters with Gate Turn-off Thyristors
}

\author{
Yevhen Fediv*, Olha Sivakova, Vladyslav Lysiak, Mykhailo Korchak \\ Lviv Polytechnic National University, 12 Stepan Bandera St., Lviv, 79013, Ukraine
}

Received: October 15, 2021. Revised: November 11, $2021 . \quad$ Accepted: November 18, 2021.

(c) 2021 The Authors. Published by Lviv Polytechnic National University.

\begin{abstract}
Using the developed models in the "Simulink" visual programming environment of the "Matlab" application package using the "SimPowerSystem" and "Simscape Electrical" libraries, a comparative analysis of methods and techniques for limiting switching overvoltages in power converters, which are controlled by unlocking two-operation thyristors, was performed. The choice of a specific means of limitation is individual for each converter and depends on many factors - the power of the converter, the current-voltage characteristics of thyristors, the parameters of the power supply, and so on. Studies have shown that the most effective protection against voltage pulses with short duration and significant amplitude is the use of "Transient Voltage Suppressors" limiting diodes, the action of which is based on the use of avalanche breakdown during the time of thyristor unlocking.
\end{abstract}

Keywords: switching overvoltages; current power converters; thyristor; limiting diode; varistor.

\section{Introduction}

The application of intelligent technologies in the power supply (transition to Smart Grid technology) in order to increase the reliability, efficiency, environmental friendliness and safety of electricity supply systems requires the implementation of energy and information flow management. In the Smart Grid concept, the problem of regulating the flow of electric power is supposed to be solved by means of power electronics and, first of all, by means of converters based on fully controlled power thyristors and transistors [1].

Modernization of devices with elements of power electronics by replacing outdated single-operation thyristors with modern two-operating thyristors allows operating them in modes with a wide range of adjustment of shear angles of the main harmonic of current, i.e. in modes of both consumption from a network and generation in a network using thyristor opening modes of electric circuits [2]-[4]. The operation of rectifiers, inverters, AC regulators for various purposes, etc. in such modes is a resource for the organization of virtual reactive power sources, as an effective tool available to the operator of the power distribution system to address dynamic reactive power compensation and high-speed reactive power balances, which is important for the increase in the stability of the load nodes, maintaining appropriate voltage levels in the network and ensuring quality and reliable supply of electricity to consumers.

The operation of power-controlled static converters in normal operating modes is accompanied by switching transients associated with changes in energy reserves in the elements of the network and electrical installations, as a result of periodic changes in the conductivity of semiconductor valves. One of the important consequences of the use of GTO (Gate Turn-Off) thyristors is the possibility of switching overvoltages in the control modes of power converters by unlocking the thyristors with control pulses. Due to the inductive nature of the resistance of the power

* Corresponding author. Email address: yevhen.i.fediv@lpnu.ua

This paper should be cited as: Y. Fediv, O. Sivakova, V. Lysiak, M. Korchak. Switching overvoltages protection of power electronics converters with gate turn-off thyristors. Energy Engineering and Control Systems, 2021, Vol. 7 , No. 2, pp. 103 - 110. https://doi.org/10.23939/jeecs2021.02.103 
supply or load during the time of closing the valves, voltage pulses occur, usually of significant multiplicity and short duration, which are called inductive voltage emissions

$$
u_{L}(t)=L_{s} \frac{d i_{b r}}{d t},
$$

where $L_{s}$ is the inductance of the circuit break $i_{\mathrm{br}}$.

Due to the significant energy efficiency of fully controlled thyristors in power converters for flexible AC transmission systems, direct thyristor control of shunt capacitor banks or rectifiers of technological installations with improved power factor, due to the use of switching modes in thyristor switching modes is especially relevant.

\section{Review of existing solutions}

Power voltage converters, for example, especially popular today voltage inverters, as the main type of converter for intelligent networks, are equipped with fully controlled power semiconductor valves with reverse diodes, which, in fact, perform the function of limiting overvoltages in multiple switching times of each valve formation of one period of output voltage.

In power converters with fully controlled power valve modules, reverse diodes are not used, so for damping of internal switching overvoltages in single modes of their unlocking at each period of alternating voltage the grid should use known means of transient energy control. Inductive emissions of switching overvoltages, as a result of rigid switching of electrical circuits, accompany the operation of contactless (semiconductor) electrical devices. In [5] the analysis of processes, methods of calculation of switching overvoltages and recommendations on their limitation are given.

In the general case, the principle of protection of electrical equipment from impulse overvoltages is based on the use of snubs - damping links for dissipation or withdrawal from the electrical network of electromagnetic pulses of external or internal origin, which generate overvoltages. The below can be used as snubs:

1) non-linear surge arresters (metal oxide varistors, MOV), the use of which is mandatory according to PUE [6];

2) protective RC or RCD links;

3) voltage limiters with sharply nonlinear I - V characteristics: varistors, Zener diodes and suppressors.

MOVs in electrical networks are the main means of protecting electrical equipment of power supply systems from lightning and switching internal overvoltages. The design and characteristics of industrial arresters are focused on the ability to absorb and scatter significant amounts of energy during electromagnetic transients in the transmission and distribution networks [7]. To protect surge-sensitive equipment, semiconductor converters are not efficient enough due to insufficient speed, low sensitivity and instability of characteristics.

Snubber links are built on the principle of reducing the rate of voltage rise by capacitors, closing the transient current, unload the semiconductor devices from the switching power and eliminate or reduce the switching pulse electrical overvoltages. Limiting of switching overvoltages by means of snub links with capacitors with a capacity of several microfarads and resistors with a resistance of several tens of ohms is most effective for low-power converters [8]. As the power increases, the losses in the snub resistors, which should be equipped with each power valve module of the converter, become significant.

Modern two-operational semiconductor devices are resistant to voltage rise rates on them, so it is especially important to limit the amplitude of the voltage emission. Semiconductor limiting transient-voltage-suppression (TVS) diodes, or suppressors, the limiting section of the I $-\mathrm{V}$ characteristics of which is formed on the basis of the use of the avalanche breakdown phenomenon of a weakly doped semiconductor structure [9], cope with this task most effectively. Limiting silicon Zener diodes, the limiting section of the I - V characteristics which is formed on the basis of the use of the tunnel breakdown phenomenon in a strongly doped semiconductor structure, are designed to regulate low voltage and are not designed for high pulses. Modern metal oxide varistors are also able to protect electrical equipment from surges, but they are of lower quality in terms of stability and reliability [10]-[13].

As shown in [14], the most effective is a combined protection against switching overvoltages with a combination of several methods and technical means of limitation. 


\section{Main part}

From a technical point of view, the available industrial resources are sufficient to limit the switching overvoltages during the unlocking of fully controlled semiconductor devices and, accordingly, to ensure electromagnetic compatibility of power converters with improved energy performance. The choice of a specific design of snobbery units depends on the power and duration of overvoltage pulses, which, in turn, are determined by the type and power of the converter, the characteristics of power semiconductor elements, power supply and load parameters, and so on. This means that the task of limiting impulse overvoltages is to select protective equipment according to certain characteristics and properties for each converter in particular. The aim of this study is to develop models and illustrate the ability and effectiveness of limiting switching overvoltages in current converters, which are controlled by the method of closing two-operation thyristors, including rectifiers, dependent inverters, thyristorcontrolled shunt capacitors, voltage regulators and more.

As a basic and universal way to limit internal switching overvoltages for converters with fully controlled thyristors, the use of limiting diodes and varistors. To prove their effectiveness, a number of models have been created in the Simulink visual programming environment of the Matlab software package using the SimPowerSystem and Simscape Electrical libraries.

The input data for an approximate estimate of the multiplicity of overvoltages in the shutdown mode of a fully controlled thyristor are the time characteristic of the shutdown mode and the parameters of the interrupt circuit. Fig. 1 shows the current-time characteristic of the shutdown mode of a fully controlled thyristor, approximated by two characteristic segments, which is implemented in the matlab model of a two-operation thyristor GTO [15].

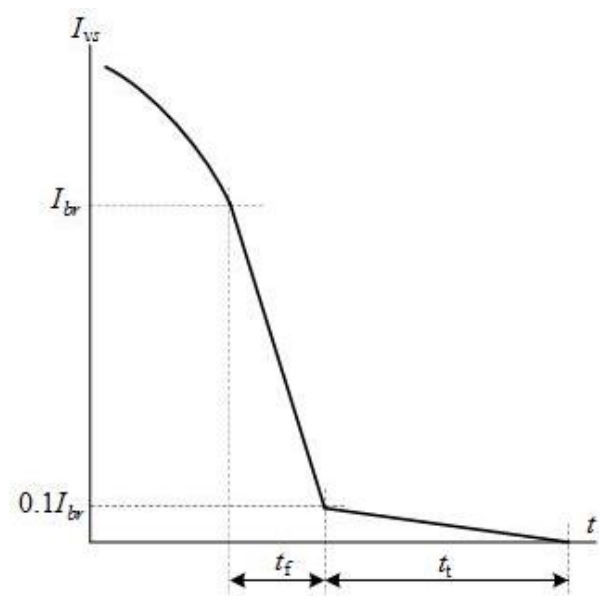

Fig.1. Time diagram of the mode of shutdown of the two-operation thyristor: $t_{\mathrm{f}}$ - duration of main switching phase; $t_{\mathrm{t}}$ - duration of the last switching phase.

Approximately, the main stage of unlocking the thyristor with a control pulse lasts for a period of time to reduce the current to $10 \%$ of the current value at the beginning of the switching process (Fig. 1). With this in mind, the expected value of the internal peak inductive overvoltage can reach the value

$$
U_{v s, \max }=E_{m}+L_{s} \frac{0.9 I_{b r}}{t_{f}}
$$

where $E_{m}$ is the amplitude of the electromotive force (EMF) of the power supply in the circuit; $I_{b r}$ is current value at the time of thyristor shutdown.

According to (2), the limitation of the overvoltage level in the thyristor unlocking mode can be achieved by slower unlocking, i.e. by increasing the time $t_{\mathrm{f}}$, but this contradicts the current trend of development of the element base of power electronics. The use of dual-operation thyristors in the power converters for which they are manufactured requires the fastest switching and closing operations. The quality of the conversion function in the voltage converters is higher, the higher the switching frequency and the shorter the process of switching off the thyristor. This is what technical progress in the development of the element base of modern power conversion 
technology is aimed at. Unlike voltage converters, thyristors in power converters operate on the mains frequency, which allows you to increase the time of the thyristor shutdown process. But this option is not optimal, because dualoperation thyristors with slower unlocking, which belong to the older generation of thyristors, have increased switching and control losses.

If it is impossible to influence the level of switching overvoltages, it is necessary to consider the effectiveness of reducing their impact with limiters with sharply nonlinear volt-ampere characteristics. Such characteristics are characteristic of nonlinear resistors (metal oxide varistors, MOV), which appeared to replace varistors based on silicon carbide (Fig.2), as well as for limiting diodes TVS, the external characteristics of which contain the avalanche breakdown of the diode (Fig.3).

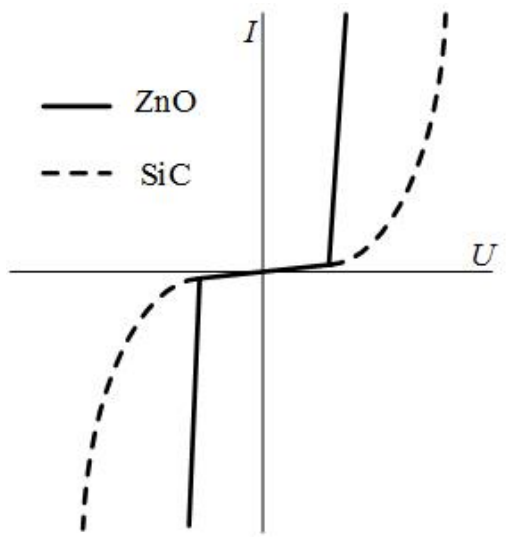

Fig.2. Volt-ampere characteristics of a varistor based on zinc oxide and silicon carbide.

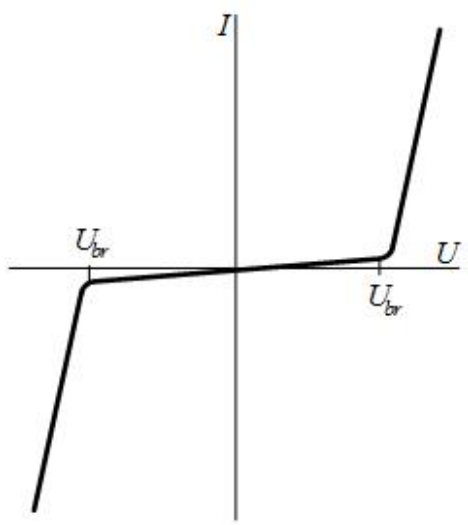

Fig.3. Volt-ampere characteristic of a bidirectional TVS diode.

Volt-ampere characteristics of surge arresters are described by the equation

$$
i=I_{\mathrm{o}}\left(\frac{u}{U_{\mathrm{o}}}\right)^{a}
$$

where $i, u$ are instantaneous values of current and voltage; $U_{\mathrm{o}}$ is voltage threshold; $I_{\mathrm{o}}$ is the magnitude of the current of the device, at a voltage threshold; $a$ is the exponent that determines the nonlinearity of the device, usually in the range from 0 to 50 .

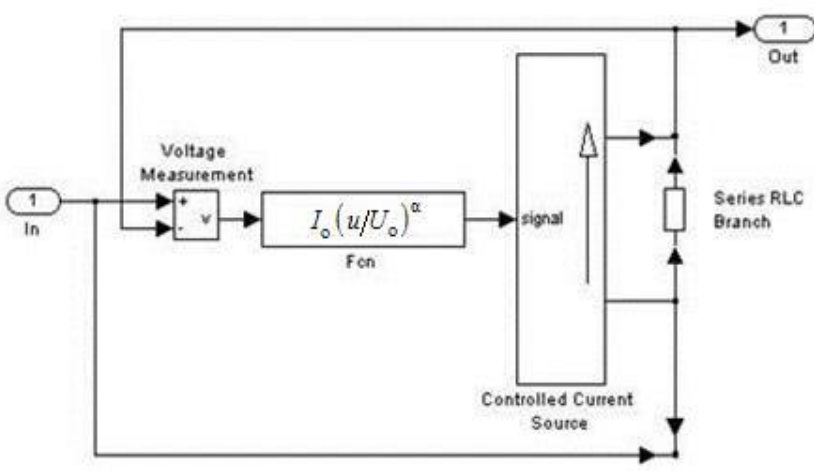

Fig. 4. The scheme of the surge arrester model.

The structure of the model of the surge arrester based on SimPowerSystems blocks is shown in Fig.4. The input of the model is a voltage signal proportional to the voltage on the device, and the output is a signal proportional to the 
current of the device. Between the output of the voltage meter and the input of the current source included Simulinkmodel, which implements the nonlinear characteristic (3) [15].

We will show the principle of limitation on the example of the simplest converter - single-phase one-and-a-halfperiod rectifier, and to illustrate processes we will consider two characteristic types of converters made on fully controlled thyristors: single-phase bridge controlled rectifier with improved energy characteristics, which in the technology of intelligent networks can organize a virtual source of reactive power (Fig.6).

Simulink model based on the resources of the SimPowerSystem library to study the effectiveness of limiting switching overvoltages using a metal oxide varistor MOV, connected in parallel to the power inputs of a single-phase bridge rectifier, is shown in Fig.7.

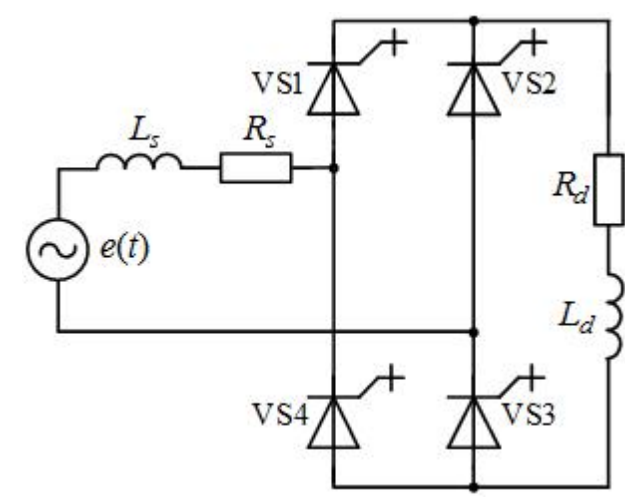

Fig.5. Equivalent circuit of a single-phase bridge rectifier.

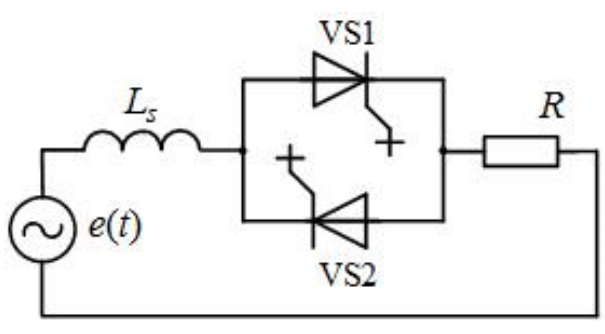

Fig.6. Equivalent circuit of one phase of the AC regulator.

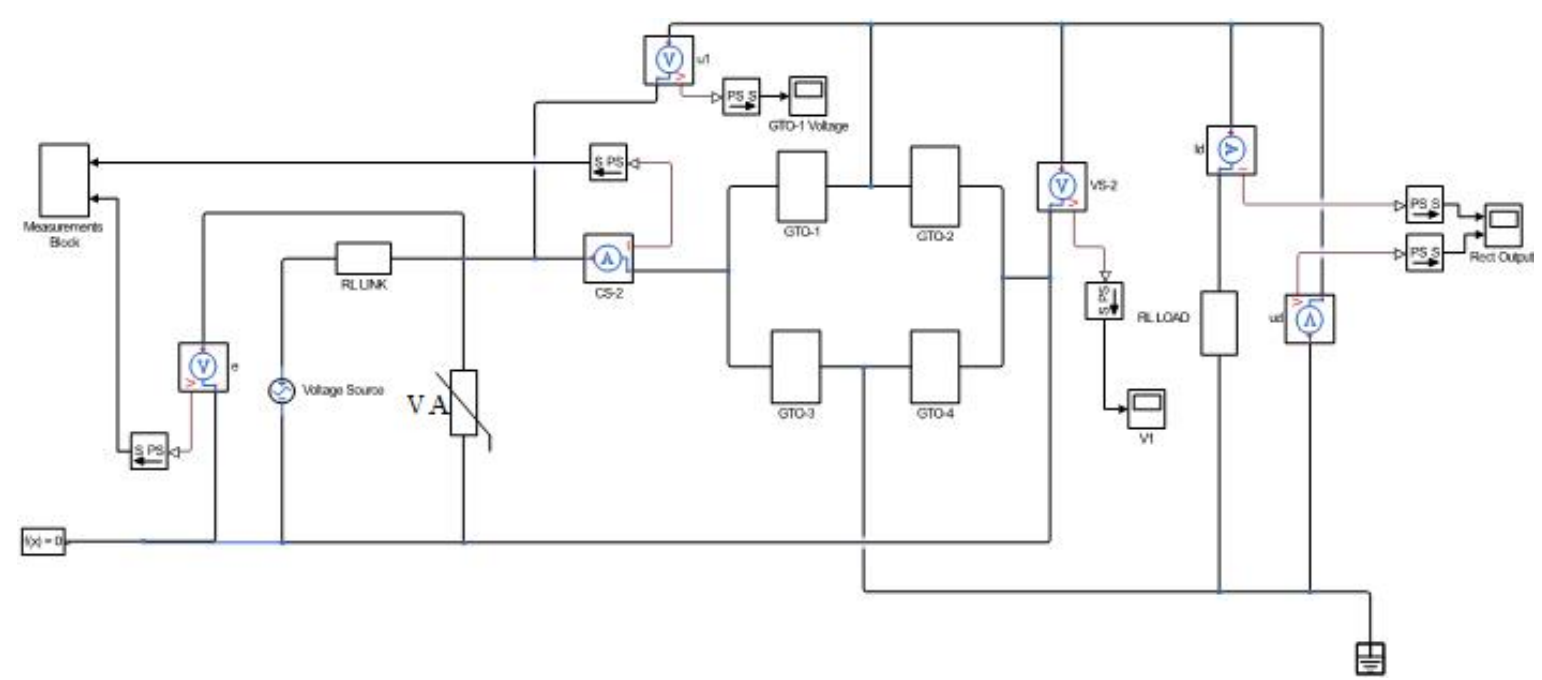

Fig.7. Simulink model for studying the modes of operation of a single-phase bridge rectifier.

Figure 8 shows the time diagram of the voltage on the thyristors GTO-1 of the rectifier (Fig.7) in the absence of means of limiting the pulse overvoltages for the mode of operation with natural angles of thyristors $\left(\alpha_{0}=0^{\circ}\right)$, and closing them ahead $\left(\alpha_{c}=120^{\circ}\right.$ electr. deg) relative to the natural closing times. The diagrams are obtained by the following parameters of the circuit: $E_{\mathrm{m}}=1000 \mathrm{~V}$ the amplitude value of the sinusoidal voltage of the power supply, $L_{\mathrm{s}}=10 \mathrm{mH}$ the inductance of the power supply, $R_{\mathrm{d}}=100 \Omega, L_{\mathrm{d}}=0$ the load, and the duration of the main phase of the shutdown of thyristors $t_{\mathrm{f}}=20 \mu \mathrm{s}$. With this method of controlling the rectifier at the time of closing the thyristors by the control current due to the presence of inductance in the circuit of the current cutout there are 8.3 times the pulse overvoltage $\left(U_{\max } \approx 8300 \mathrm{~V}\right)$. 


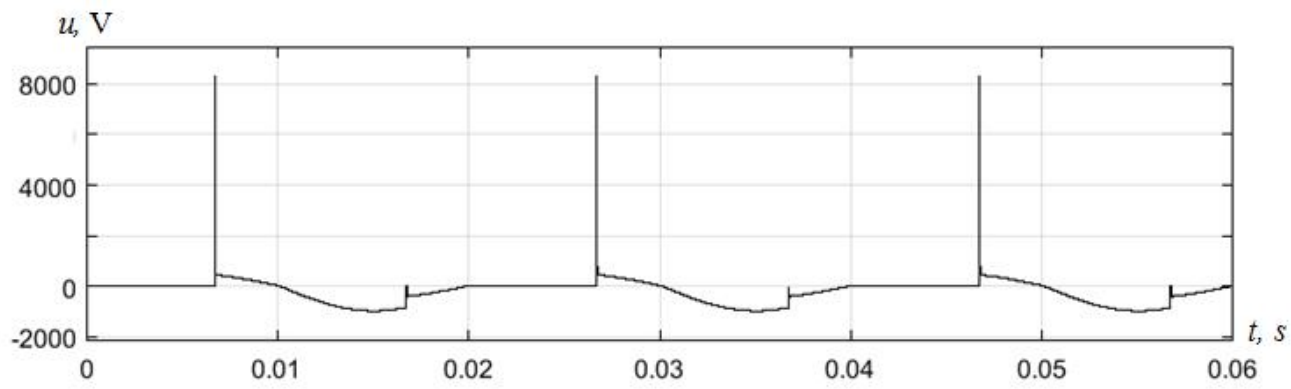

Fig.8. Time diagram of the voltage on the thyristor of a single-phase bridge rectifier without surge arrester.

Switching on the MOV varistor modeled according to Fig.4 of parameters $U_{\mathrm{rvs}}=1000 \mathrm{~V}, I_{\mathrm{o}}=500 \mathrm{~A}, \alpha=50^{\circ}$ in parallel to the inputs of the $\mathrm{AC}$ voltage of the bridge rectifier allows you to limit the overvoltage pulses on the thyristors of the rectifier to the level of the amplitude of the AC voltage of the power supply (1000 V).

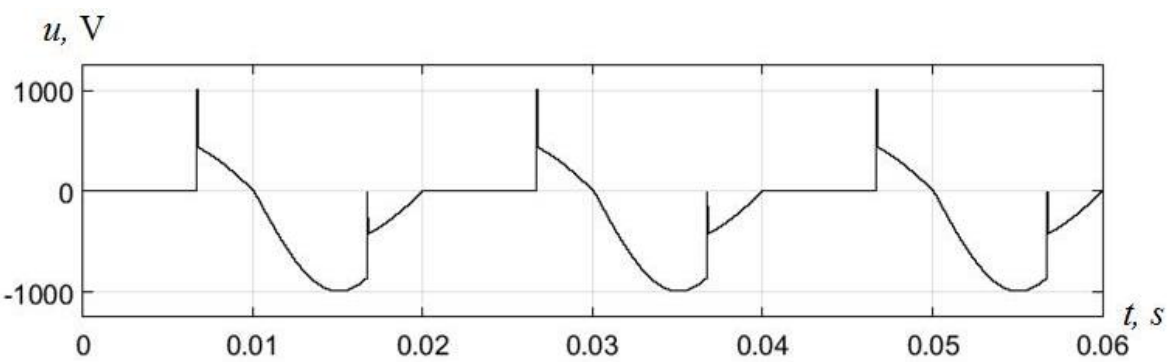

Fig. 9. Time diagram of the voltage on the thyristor of a single-phase bridge rectifier for limiting overvoltages by means of a varistor.

Simulink model based on the resources of the Simscape Electrical library, developed to study the effectiveness of limiting switching overvoltages in a voltage regulator with fully controlled thyristors using limiting diodes TVS, is shown in Fig.10.

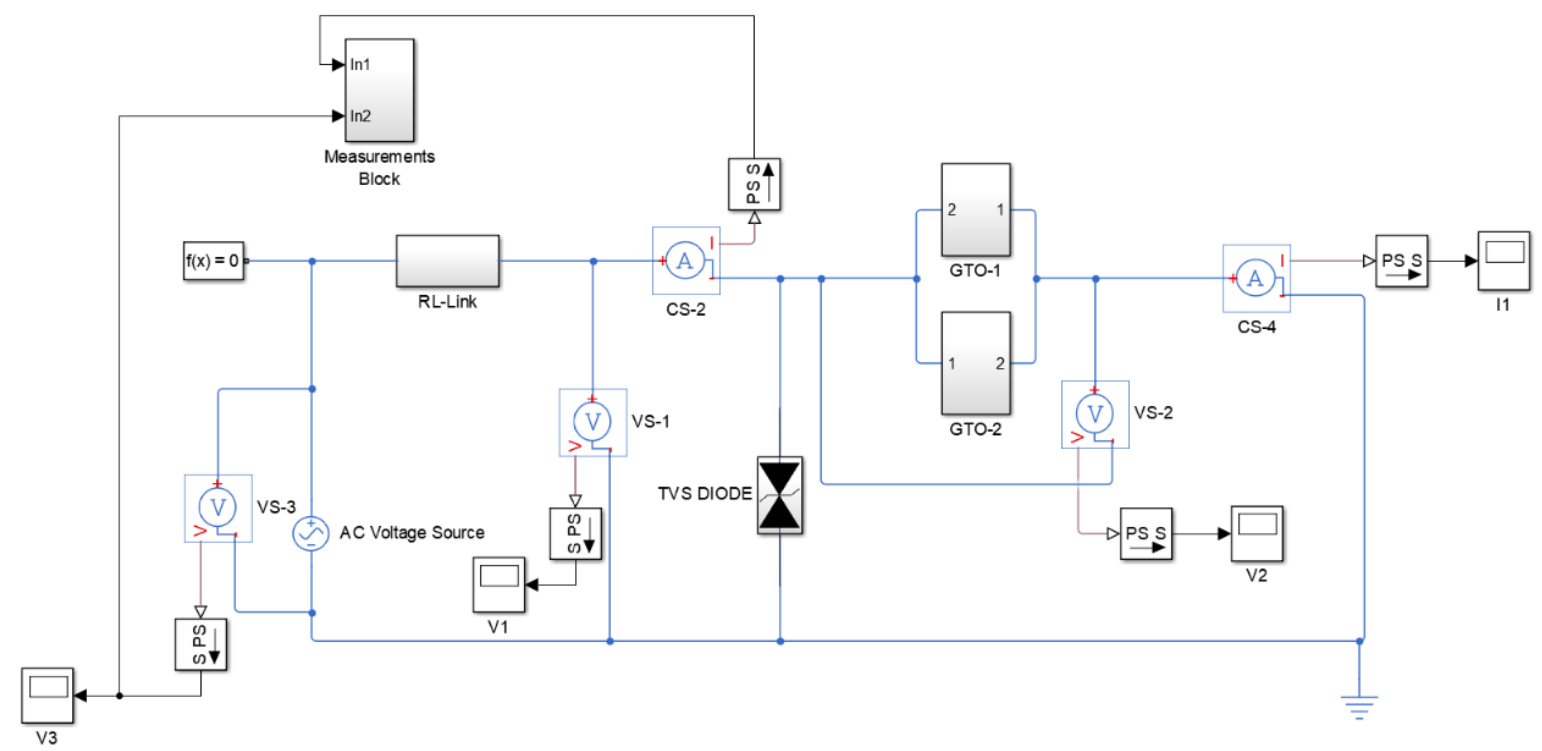

Fig.10. Simulink model for studying the modes of operation of a single-phase voltage regulator with GTO thyristors. 


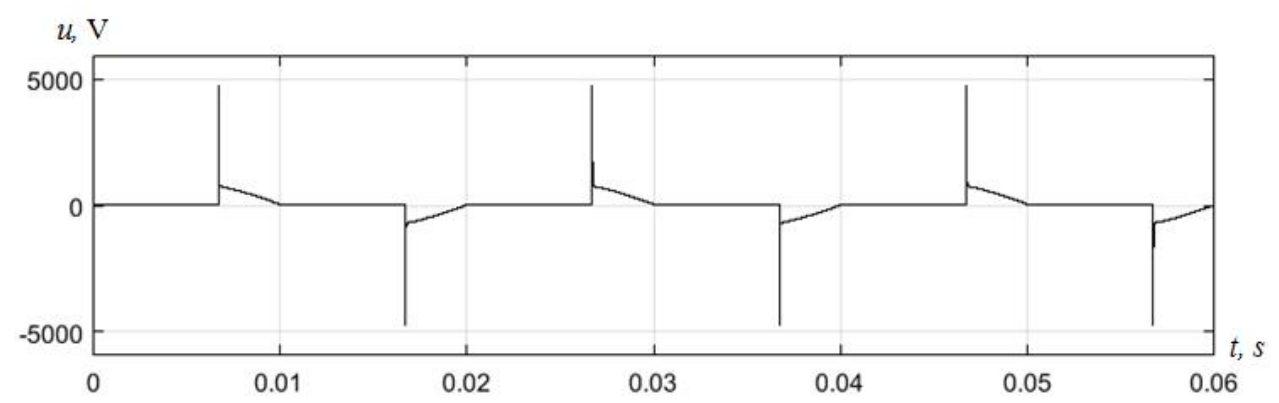

Fig.11. Time diagram of the voltage on the counter-parallel switched GTO thyristors of voltage regulator without means of limiting switching overvoltages.

Figure 11 shows the timing diagrams of the voltage on the thyristors of the regulator in the control mode ahead of the closing times of the thyristors $\left(\alpha_{0}=0^{\circ}, \alpha_{c}=120^{\circ}\right)$ without means of limiting switching overvoltages for the parameters of the circuit, and. $E_{\mathrm{m}}=1000 \mathrm{~V}, L_{\mathrm{s}}=20 \mathrm{mH}$ and $R=100 \Omega$. At the time of closing the thyristors there are switching overvoltages with a peak value of $4800 \mathrm{~V}$, which is 4.8 times the voltage of the power supply.

To limit them, a symmetrical TVS diode is connected in parallel to the thyristors. The principle of operation of the protective diode is based on the phenomenon of reverse breakdown. If a voltage with the amplitude greater than a certain level of VBR (breakdown voltage) is applied to the TVS, a breakdown will begin with an avalanche-like increase in current carriers. The current flowing through the diode increases almost indefinitely, and the voltage hardly changes. As a result, the input voltage is limited, i.e. the TVS diode can be in one of two states: off or in limit mode.

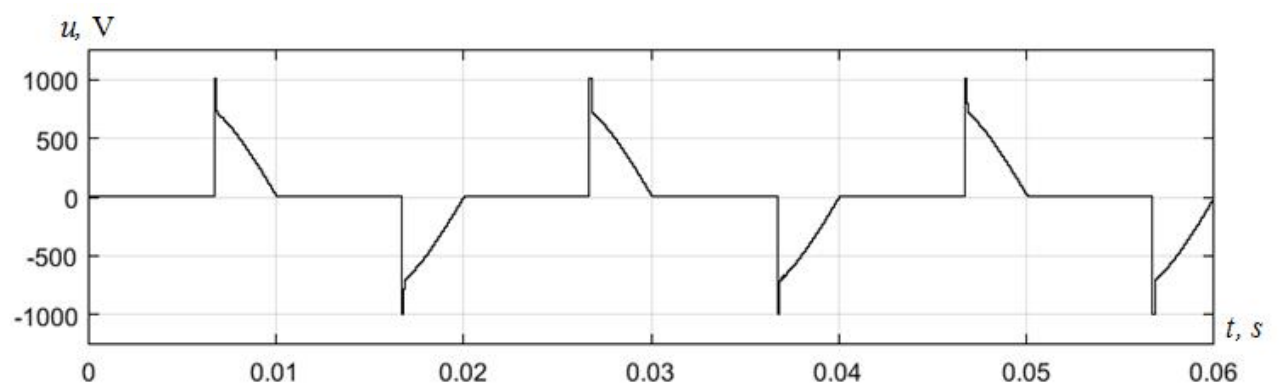

Fig.12. Time diagram of voltage on the thyristors of the regulator with a symmetrical limiting diode.

Fig. 12 shows the timing diagrams of the voltage on the thyristors of the regulator with the limitation of switching overvoltages at the time of closing the thyristors using TVS diodes with limiting voltage $U_{\mathrm{rvs}}=1000 \mathrm{~V}$. As can be seen from the voltage diagram, the symmetrical limiting diode in the studied circuit limits the overvoltage pulses to a value of $1000 \mathrm{~V}$.

\section{Conclusion}

A sharp drop in current due to the inductance of the power supply network due to the closing of the thyristors by the control pulse can lead to pulse overvoltages on the elements of power semiconductor current converters made using fully controlled thyristors.

To protect electrical equipment from switching overvoltages in current converters with fully controlled semiconductor valves (rectifiers, dependent inverters, thyristor-controlled shunt capacitor banks, voltage regulators, etc.), the use of semiconductor limiters was proposed - metal oxide varistors and power limiting diodes, which should be connected in parallel to the power supply network or to the terminals of dual-operation thyristors.

Developed models in the visual programming environment Simulink Matlab application package using the libraries SimPowerSystem and Simscape Electrical and conducted studies of electromagnetic processes in the rectifier 
and voltage regulator, built on fully controlled thyristors, confirmed the effectiveness of both switching voltage options.

\title{
References
}

[1] Intelligent electrical networks: elements and modes: For general. ed. acad. NAS of Ukraine O.V. Kyrylenko. - Kyiv: Institute of Electrodynamics of the National Academy of Sciences of Ukraine, 2016. - 400 p. (in Ukrainian)

[2] Y. Fediv, O. Sivakova, M. Korchak (2019). Model of Virtual Source of Reactive Power for Smart Electrical Supply Systems. 2019 IEEE 20th International Conference on Computational Problems of Electrical Engineering (CPEE). 15-18 Sept. 2019, Lviv-Slavske, Ukraine. doi:10.1109/CPEE47179.2019.8949159

[3] Y. Fediv, O. Sivakova, M. Korchak (2020). Multi operated virtual power plan in smart grid, Adv. Sci. Technol. Eng. Syst. J. 5(6), 256-260 (2020). doi:10.25046/aj050630

[4] M. Korchak, O. Sivakova, Y. Fediv (2018). Virtual source of reactive power in electricity supply systems of household consumers, Proceedings of international forum «Litteris et Artibus», November 22-24 th, 2018, Lviv, Ukraine. doi: 10.23939/lea2018.0116.

[5] A. Soskov. N. Salabaeva, Y. Forkun, M. Glebova. Methods of overvoltage limitation in modern de semiconductor switching apparatus and their calculation. Eastern-European Journal of Enterprise Technologies. 3/8 (81) 2016. doi:10.15587/1729-4061.2016.72533

[6] Electrical Installations Code. Minenergovuhillia of Ukraine, 2017. - 617 p. (in Ukrainian)

[7] J. Magnusson, R. Saers, L. Liljestrand, G. Engdahl. Separation of the Energy Absorption and Overvoltage Protection in Solid-State Breakers by the Use of Parallel Varistors. IEEE transactions on power electronics, vol. 29, no. 6, June 2014. doi:10.1109/TPEL.2013.2272857

[8] TND335/D. Transient Overvoltage Protection, ON Semiconductor, Semiconductor Components Industries. LLC, 2008.

[9] AN 1826/0104. Transient Protection Solution: Transil diode versus Varistor /Bremond A., Karoui C. — STMicroelectronics.

[10] Han S. M., Huh C. S., Choi J. S. A Validation of Conventional Protection Devices in Protecting EMP Threats // Progress in Electromagnetic Research. 2011. Vol. 119.

[11] Howell T. Comparing Circuit Protection Technologies for 48 V DC in High Surge Environments. Protection Engineers Group Conference, Dallas, March 14-16, 2017.

[12] Novikov P. Protection of power Transistor. Part 1. Overvoltage. Power Electronics, № 4 (37), 2012, pp. 10-14. (in Russian)

[13] Mathworks HelpCenter Documentation. https://www.mathworks.com/help/physmod/sps/powersys/ug/building-and-customizing-nonlinearmodels.html

[14] J. Goldman, Selecting Protection Devices: TVS Diodes vs. MetalOxide Varistors // Power Electronics. 2010 . June 1.

[15] IEC 60255-1. Measuring relays and protection equipment - Part 11: Voltage dips, short interruptions, variations and ripple on auxiliary power supply port.

\section{Захист від комутаційних перенапруг силових перетворювачів струму 3 вимикаючими тиристорами}

\author{
Євген Федів, Ольга Сівакова, Владислав Лисяк, Михайло Корчак
}

Наџіональний університет «Львівська політехніка», вул. Степана Бандери, 12, Львів, 79013, Україна

\section{Анотація}

За допомогою розроблених моделей в середовищі візуального програмування "Simulink" пакету прикладних програм "Matlab" з використанням бібліотек "SimPowerSystem" та "Simscape Electrical” здійснено порівняльний аналіз способів та технічних засобів для обмеження комутаційних перенапруг в силових перетворювачах струму, які керовані відмиканням двоопераційних тиристорів. Вибір конкретного засобу обмеження $є$ індивідуальним для кожного перетворювача і залежить від багатьох факторів - потужності перетворювача, вольт-амперних характеристик тиристорів, параметрів мережі живлення тощо. Дослідження показали, що найбільш ефективним захистом від імпульсів напруги 3 малою тривалістю та значною амплітудою є застосування обмежувальних діодів “Transient Voltage Suppressors", дія яких грунтується на використанні явища лавинного пробою на проміжку часу режиму відмикання тиристора.

Ключові слова: комутаційні перенапруги; силовий перетворювач струму; тиристор; обмежувальний діод; варистор. 